\title{
The partnership between the Brazilian School Feeding Program and family farming: a way for reducing ultra-processed foods in school meals
}

\author{
Carla Rosane Paz Arruda Teo* \\ Universidade Comunitária da Região de Chapecó (Unochapecó), Graduate Program in Health Sciences, \\ Avenida Atílio Fontana 591E, Bairro Efapi, CEP 89809-000, Chapecó, SC, Brazil
}

Submitted 22 0ctober 2016: Final revision received 7 July 2017: Accepted 11 July 2017: First published online 30 August 2017

\begin{abstract}
Objective: To evaluate the profile of food acquisition in the National School Feeding Program according to the extent and purpose of food processing in three municipalities of southern Brazil during the implementation period of Law 11.947/ 2009.

Design: Descriptive cross-sectional study. Data for 2008-2010 involved quantities, prices and types of suppliers for food items purchased. In total, 1529 purchases were analysed. The items were classified into the following groups: G1 (unprocessed/minimally processed), G2 (culinary ingredients), G3 (processed), G4 (ultra-processed). Quantities of purchased foods were converted into energy and average prices (\$US/4184 kJ $(1000 \mathrm{kcal})$ ) were calculated. The proportion of each food group in total purchases was expressed as both a percentage of total energy and a percentage of total expenditure. Data analysis was carried out in Stata version 12.1.

Setting: Three municipalities in southern Brazil.

Results: Relative contribution to total energy purchased was high for G1 (49.8\%; G2, $23.8 \%$; G3, 4.5\%; G4, 21.8\%). Among acquisitions from family farming, G1 represented $51.3 \%$ of the total energy purchased; G2, 9.9\%; G3, 19.7\%; G4, $19 \cdot 0 \%$. Total cost was as follows: G1, 61.6\%; G2, 3.9\%; G3, 18.5\%; G4, 16.0\%. Prices for food products from family farms were consistently higher. Average price from family farms was 1.3 ; from conventional suppliers, $0 \cdot 9$.

Conclusions: The implementation of Law 11.947/2009 produced a positive effect on the regional profile of food purchases for the School Feeding Program. However, there is still considerable potential to promote health by strengthening relationships between family farming and school feeding.
\end{abstract}

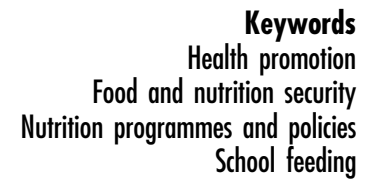

Keywords nutrition security School feeding
The National School Feeding Program (Programa Nacional de Alimentação Escolar (PNAE)) is one of the oldest and most established social initiatives for food and nutrition in Brazil, and is led by the federal government ${ }^{(1)}$. Considered a formidable example of social policies promoting food security, the programme was launched in the 1940s and gained legal status in $1955^{(2)}$. The PNAE is currently recognized as one of the broadest school feeding initiatives in the world, covering 43 million Brazilian students of all social strata in primary education, or approximately $20 \cdot 0 \%$ of the Brazilian population ${ }^{(3)}$.

Over the past 60 years, the objectives and hallmarks of the programme have changed substantially. Although in the beginning the focus was centred on fighting malnutrition $^{(4)}$, the PNAE now aims to contribute to bio-psychosocial development, learning, overall school performance, the promotion of healthy eating habits through food and nutrition education, and the provision of school meals that meet the nutritional needs of children ${ }^{(5)}$.

Likewise, legislation governing the programme has also evolved, allowing the PNAE to be utilized as a means for and mechanism of local development ${ }^{(5)}$. Since its inception, the programme was geared indirectly towards support of local production $^{(4)}$ by adapting menus to regional production and culture. However, the political, social and economic contexts of the time led to the gradual inclusion of processed food products in school menus, compromising both the social and nutritional components of the programme in early decades. These food products were initially donated by international entities and were subsequently produced in Brazil from the 1970s onwards ${ }^{(1)}$.

Only four decades later, new legislation emphasized the need to include regionally grown items in school menus, culminating in the decentralization of the programme in 
1994 and consequent reduction in the use of highly processed food products in school meals ${ }^{(1)}$. More recently, in 2009, Law $11.947 / 2009^{(5)}$ stipulated support for local and sustainable development by highlighting the role of family farming. According to this regulation, a minimum of $30 \cdot 0 \%$ of federal programme funds must be invested in the acquisition of foods produced by family farming, preferentially regional suppliers. However, distinct nomenclature or stipulation of foodstuffs eligible for acquisition is not currently available ${ }^{(6)}$.

Rapid demographic, epidemiological and nutritional transition in Brazil over the last decades has resulted in marked increases in weight gain indices, obesity and noncommunicable chronic diseases in all population groups. The nutritional profile of the Brazilian population is complex and school feeding has the potential to lead to significant changes in this scenario, especially since the eating habits developed in childhood and adolescence are likely to last into adulthood ${ }^{(7,8)}$.

Given the scope and national remit of school feeding programmes, such initiatives can constitute important dimensions of both public health and local development ${ }^{(4,9)}$. Partnerships between the School Feeding Program and family farming can thus be considered a viable strategy to strengthen these initiatives, thereby qualifying the programme as a mechanism for local development and food security.

The objective of the present study was to evaluate the profile of PNAE food acquisitions according to the extent and purpose of food processing in three municipalities in southern Brazil during the implementation period of Law $11.947 / 2009^{(5)}$.

\section{Methods}

A cross-sectional, descriptive study was undertaken in three municipalities in the state of Santa Catarina, southern Brazil, selected for proximity to the area of the university where the research was carried out. We used nonprobabilistic sampling (a convenience sampling method) consisting of selecting elements that are accessible, available and convenient for studying the focal population(s). This sampling method offers agility and lower operational costs, making the research more feasible. For our research, the selected municipalities met the following criteria: they were located near the university (between 24 and $63 \mathrm{~km}$ (15 and 39 miles)) and the local authorities allowed data collection.

Annual data were gathered for the period between 2008 and 2010 to facilitate direct comparison of metrics from the year immediately prior to the adoption of Law 11.947/ $2009^{(5)}$ and the year of its adoption.

\section{Characterization of the municipalities surveyed}

Research was conducted in three municipalities (hereafter referred to as 'city A', 'city B' and 'city C') in the mesoregion of western Santa Catarina state. The sample cities have primarily agricultural socio-economic profiles characterized by the predominance of small farms and family agriculture $^{(10)}$.

City A has a population of 25713 (81.5\% urban and $18.5 \%$ rural), a Human Development Index (HDI) value of 0.809 and a city poverty index (Índice de Pobreza Municipal (IPM)) of $29 \cdot 9 \%^{(11)}$. There is a network of eighteen municipal schools in the city serving 2551 students enrolled in primary education ${ }^{(12)}$. The local economy is focused on agriculture and $95.0 \%$ of the 1200 farms in the municipality are family-owned ${ }^{(10,13)}$.

City B has 44128 habitants (88.7\% urban and $11.3 \%$ rural), an HDI of $0 \cdot 815$ and an IPM of $32 \cdot 2 \%{ }^{(11)}$. In this city, twenty-seven schools serve 2346 students in primary education ${ }^{(10)}$. Once again, agriculture is the primary focus of the city economy, where $80.0 \%$ of the 960 farms in the municipality are family-owned ${ }^{(12)}$.

City C has 10661 habitants $(72.4 \%$ urban and $27.6 \%$ rural), an HDI of 0.819 and an IPM of $32.3 \%{ }^{(11)}$. A total of ten primary schools serve 1254 students $^{(12)}$. The city has 678 farming establishments, mostly family-owned (the exact proportion was not available at the time the study was concluded). The paper industry and agriculture are the main economic production activities in the city ${ }^{(14)}$.

\section{Data collection and organization}

Gathered data included the amounts (quantities and units), prices and types of suppliers (farmer or conventional/non-farmer) for food items purchased through the programme. This information was obtained directly from the Departments of Education and Agriculture for each municipality, which provided the reports of the municipal purchasing systems for school feeding during the research period. In total, 1529 purchases (i.e. programme acquisitions) were analysed.

\section{Conversion of purchased foods into energy}

Records of PNAE food acquisitions in the three municipalities were grouped into 136 food items. Initially, quantities of the same items purchased in the same county and year were summed. Since these acquisitions are used for school meals, total quantities were divided among 200 school days, providing average daily quantities for each food item. When appropriate, correction factors ${ }^{(15)}$ were applied to the average quantities to exclude the inedible fraction of each item. A cooking index was also applied to convert the weight of each food item into an estimated weight of consumption. This was necessary for $38.97 \%$ of food items (fifty-three items), with correction factors being applied mainly to fruits, vegetables and meat cuts with bone, and the cooking index applied for cereals and beans, meats, roots and some vegetables.

Finally, the net average daily quantity of each food item was converted into energy (kilocalories; $1 \mathrm{kcal}=4 \cdot 184 \mathrm{~kJ}$ ) using the Brazilian Official Food Composition Table (Tabela Brasileira de Composição de Alimentos $($ TACO $))^{(1)}$. 
The US Department of Agriculture's National Nutrient Database for Standard Reference ${ }^{(17)}$ was used for three $(2 \cdot 2 \%)$ ultra-processed items not available in TACO.

\section{Grouping of foodstuffs}

Food items were classified according to the NOVA classification proposed by Monteiro et al. ${ }^{(18)}$ based on the nature, extent and purpose of processing. This scheme divides foods into four groups: Group 1 (unprocessed or minimally processed); Group 2 (processed culinary ingredients); Group 3 (processed foods); and Group 4 (ultra-processed food and drink products).

\section{Price deflation of food items acquired through the programme}

Considering that the present study analysed food acquisitions over a period of three years, acquisition prices (in Brazilian reais) were deflated in July 2008 using the Consumer Price Index (IPC-A) of the Brazilian Institute of Geography and Statistics and then converted into US dollars. This procedure allows the evaluation of real changes (inflation-free) in prices over the study period.

\section{Data analysis}

Data organization and descriptive/exploratory analyses were conducted using the statistical software package Stata version 12.1. The proportion of total purchases represented by each food group was expressed as both a percentage of the total energy acquired and a percentage of total expenditure (cost). The average price of each food group (\$US/1000 kcal) was also used to characterize food acquisition. Food prices were obtained by dividing total expenditure (\$US) by the amount of energy provided (kcal) for each food item, and then multiplying this value by 1000 . This was done to contextualize the prices in a nutritional perspective. This is important because it allows one to compare food prices on an isoenergetic basis ${ }^{(19)}$. We did not estimate prices for two food items with virtually no energy (1.5\%).

The participation of each food group and the participation of products from family farms in acquisitions (in terms of both energy and cost) were estimated separately for each year of the research period.

\section{Results}

Unprocessed or minimally processed items (Group 1) increased in contribution to total energy by almost 3 percentage points from 2008 to 2009, remaining at high levels (48.3\%) in 2010. This increase was based on increased acquisition of rice, beans, fruits, vegetables, roots/tubers and eggs. In Group 1, acquisition of flours and pasta reduced the most. The contribution of processed culinary ingredients (Group 2) decreased by 4 percentage points between 2008 and 2009, remaining stable afterwards.
Together these groups were responsible for almost threequarters of total energy acquired over the study period. Acquisitions of processed foods (Group 3) decreased by 1.5 percentage points over the study period, while ultraprocessed products (Group 4) increased from 20.3 to 23.2\% between 2008 and 2010. This increase was due almost exclusively to the acquisition of crackers, biscuits and cookies in 2009, and to ready-to-eat meals or powdered products (such as dessert mix powders) in 2010. The representation of most processed food subgroups and ultra-processed products decreased, including breads, sweets, sauces and breakfast cereals (Table 1). It is noteworthy that in terms of energy, the combined food acquisitions in Groups 1 to 4 and their interrelationships are far from ideal. Analysis of only 2010, the first year of mandatory application of Law $11.947 / 2009^{(5)}$, revealed no clear trends (Table 1 ).

The higher price of unprocessed or minimally processed items per unit of energy results in a disproportional contribution of this food group to total cost (much greater than the contribution to total energy), contrasting with the results for processed culinary ingredients. Due to the short time frame of the study, significant changes in food prices were not expected. However, trends in the relative contributions of food groups to total cost tended to agree with contributions to total energy (Table 2).

The proportion of purchases direct from family farms tended to increase over the study period, in terms of both energy and cost (Fig. 1). This situation represents a positive trend in the programme, as baskets acquired from family farms provide fresher foods than baskets acquired from conventional suppliers.

Analysis of direct acquisitions from family farms between 2008 and 2010 for all municipalities revealed that Group 1 represented $51.3 \%$ of the total energy; while Group 2 represented only 9.9\%, Group 3 represented $19.7 \%$ and Group 4 represented $19.0 \%$ (average proportions). The total proportion of acquisitions from family farms in terms of cost was $61.6 \%$ for Group 1, 3.9\% for Group 2, $18.5 \%$ for Group 3 and $16.0 \%$ for Group 4 (average proportions). These data suggest that the acquisition of Group 1 foodstuffs financially burdens school feeding to a greater extent than does acquisition of other food groups. The proportions of total energy and total cost for Group 3 foods are similar, while in Groups 2 and 4 the proportion of total energy is higher than the proportion of the total cost. The proportion of total energy of Group 1 represents a high proportion of the total acquisitions from family farms.

Thus, as expected, the food basket provided by family farms presented a higher proportion of unprocessed or minimally processed foods (Fig. 2). The proportion of ultra-processed products was high in baskets from both conventional suppliers and family farms, and processed foods composed a larger share of the family farming basket. 
Table 1 Relative participation (\%) of food groups and subgroups in the total energy of PNAE acquisitions for the research period 2008-2010, National School Feeding Program (Programa Nacional de Alimentação Escolar (PNAE)), Santa Catarina, Brazil

\begin{tabular}{|c|c|c|c|c|}
\hline \multirow[b]{2}{*}{ Group/subgroup of foodstuffs } & \multicolumn{4}{|c|}{$\begin{array}{l}\text { Relative participation (\%) } \\
\text { in total energy }\end{array}$} \\
\hline & 2008 & 2009 & 2010 & Average \\
\hline $\begin{array}{l}\text { Unprocessed or minimally } \\
\text { processed (G1) }\end{array}$ & $49 \cdot 2$ & 51.9 & $48 \cdot 3$ & $49 \cdot 8$ \\
\hline Rice & 8.2 & 9.6 & $9 \cdot 6$ & $9 \cdot 1$ \\
\hline Beans & 3.2 & 3.4 & $2 \cdot 1$ & 2.9 \\
\hline Meats & 8.4 & 8.6 & $8 \cdot 3$ & 8.4 \\
\hline Milk & $5 \cdot 1$ & $6 \cdot 8$ & $5 \cdot 7$ & 5.9 \\
\hline Fruits & 4.0 & $7 \cdot 0$ & $5 \cdot 2$ & 5.4 \\
\hline Root and tuber vegetables & 1.9 & $2 \cdot 0$ & 3.4 & $2 \cdot 4$ \\
\hline Leafy vegetables & 1.2 & 1.4 & 1.4 & 1.4 \\
\hline Fish & 0.0 & 0.3 & 0.0 & 0.1 \\
\hline Eggs & 1.2 & 1.5 & 1.6 & 1.4 \\
\hline Legumes & 0.3 & 0.3 & 0.4 & 0.3 \\
\hline Cassava flour & 0.6 & 0.4 & 0.2 & 0.4 \\
\hline Pasta & 7.4 & 4.7 & 4.5 & 5.5 \\
\hline Wheat flour & $6 \cdot 9$ & $6 \cdot 1$ & $5 \cdot 2$ & $6 \cdot 1$ \\
\hline Other G1 (other cereals) & 0.8 & 0.0 & 0.7 & 0.5 \\
\hline Processed culinary ingredients (G2) & $25 \cdot 3$ & $21 \cdot 2$ & $24 \cdot 8$ & 23.8 \\
\hline Sugar & 11.8 & 9.8 & 11.0 & $10 \cdot 8$ \\
\hline Vegetable oils & $8 \cdot 2$ & 7.5 & $9 \cdot 1$ & $8 \cdot 3$ \\
\hline Animal fat (lard) & 0.4 & 0.3 & 0.7 & 0.5 \\
\hline Other starches & $4 \cdot 2$ & 3.1 & 3.0 & 3.4 \\
\hline Other G2 ( & 0.7 & 0.6 & $1 \cdot 1$ & 0.8 \\
\hline Processed foods (G3) & $5 \cdot 1$ & 4.9 & 3.6 & 4.5 \\
\hline Breads & 4.3 & 3.8 & 2.5 & 3.5 \\
\hline Cheeses & 0.8 & $1 \cdot 1$ & $1 \cdot 1$ & 1.0 \\
\hline $\begin{array}{l}\text { Ultra-processed food and drink } \\
\text { products (G4) }\end{array}$ & $20 \cdot 3$ & $22 \cdot 0$ & $23 \cdot 2$ & $21 \cdot 8$ \\
\hline Cookies, crackers, biscuits & $10 \cdot 0$ & $12 \cdot 3$ & 9.5 & $10 \cdot 6$ \\
\hline $\begin{array}{l}\text { Ice cream/chocolate/instant } \\
\text { desserts }\end{array}$ & $4 \cdot 2$ & 3.7 & 3.5 & 3.8 \\
\hline Ready-to-heat meals and mixes & 0.0 & 0.0 & 4.5 & 1.5 \\
\hline Sausage & 0.9 & 1.5 & 1.7 & 1.4 \\
\hline Instant sauces & 0.4 & 0.3 & 0.4 & 0.4 \\
\hline Margarines & $2 \cdot 4$ & 1.7 & 1.9 & $2 \cdot 0$ \\
\hline Breakfast cereals & 0.8 & 0.6 & 0.4 & 0.6 \\
\hline Other sweetened 'fruit' drinks & 1.5 & 1.6 & 1.2 & 1.5 \\
\hline Other G4 (other candies) & 0.2 & 0.2 & 0.2 & 0.2 \\
\hline
\end{tabular}

City A acquired the following foods from family farms: rice (whole and parboiled); beans and other legumes (chickpeas, organic soyabeans, lentils); meats (beef, pork, chicken); milk; fresh fruits (avocados, pineapples, bananas, bergamot, oranges, limes, lemons, apples, papayas, watermelon, peaches, tangerines, grapes); vegetables (lettuce, kale, spinach, cauliflower, broccoli, onion, cabbage, parsley, green onion, tomatoes, beets, carrots, chayote, potatoes, sweet potatoes, barley potatoes, cassava, corn cob, pumpkin); fish; eggs; cassava flour; pasta; wheat flour (whole and refined); corn flour; rice flour; oatmeal flour; tea; sugar (brown and refined) and molasses obtained from cane; honey; refined soyabean oil; lard; vinegar; corn starch; freshly made breads (with whole and refined flours); cheese; canned corn; cookies and crackers.

City B acquired: beans; meats (beef, pork); milk; fresh fruits (avocados, bergamot, oranges); vegetables (lettuce,
Table 2 Relative participation (\%) of food groups and subgroups in the total expenditure (cost) of PNAE acquisitions as well as the average price of foodstuff per group and subgroup for the research period 2008-2010, National School Feeding Program (Programa Nacional de Alimentação Escolar (PNAE)), Santa Catarina, Brazil

\begin{tabular}{|c|c|c|c|c|c|}
\hline \multirow[b]{2}{*}{ Group/subgroup of foodstuffs } & \multicolumn{4}{|c|}{$\begin{array}{l}\text { Relative participation (\%) } \\
\text { in total expenditure (cost) }\end{array}$} & \multirow[b]{2}{*}{ Price* } \\
\hline & 2008 & 2009 & 2010 & Average & \\
\hline $\begin{array}{l}\text { Unprocessed or minimally } \\
\text { processed (G1) }\end{array}$ & $64 \cdot 6$ & $65 \cdot 0$ & $65 \cdot 5$ & $65 \cdot 0$ & $1 \cdot 6$ \\
\hline Rice & 3.0 & 2.5 & $2 \cdot 3$ & $2 \cdot 6$ & 0.3 \\
\hline Beans & 2.5 & 1.6 & 1.0 & 1.7 & 0.6 \\
\hline Meats & $22 \cdot 3$ & 21.4 & $22 \cdot 6$ & $22 \cdot 1$ & 2.5 \\
\hline Milk & $7 \cdot 4$ & $10 \cdot 0$ & 7.9 & 8.4 & 1.4 \\
\hline Fruits & $7 \cdot 8$ & $12 \cdot 0$ & 8.8 & 9.5 & $1 \cdot 7$ \\
\hline Root and tuber vegetables & 2.6 & $2 \cdot 8$ & 3.5 & 3.0 & $1 \cdot 1$ \\
\hline Leafy vegetables & $5 \cdot 7$ & $6 \cdot 3$ & $9 \cdot 6$ & $7 \cdot 2$ & $5 \cdot 2$ \\
\hline Fish & 0.0 & 0.1 & 0.0 & 0.0 & $32 \cdot 4$ \\
\hline Eggs & $2 \cdot 3$ & 2.5 & $2 \cdot 2$ & $2 \cdot 3$ & 1.5 \\
\hline Legumes & 0.2 & 0.3 & 0.4 & 0.3 & 1.0 \\
\hline Cassava flour & $0 . \overline{2}$ & 0.1 & 0.1 & 0.1 & 0.3 \\
\hline Pasta & $5 \cdot 0$ & $2 \cdot 6$ & $2 \cdot 6$ & 3.4 & 0.6 \\
\hline Wheat flour & $2 \cdot 0$ & 1.3 & $1 \cdot 2$ & 1.5 & 0.2 \\
\hline Other G1 (other cereals) & 3.7 & 1.6 & 3.2 & $2 \cdot 8$ & 4.5 \\
\hline $\begin{array}{l}\text { Processed culinary } \\
\text { ingredients (G2) }\end{array}$ & $8 \cdot 1$ & $6 \cdot 1$ & $9 \cdot 6$ & $7 \cdot 9$ & 0.4 \\
\hline Sugar & $2 \cdot 2$ & 1.9 & $4 \cdot 1$ & $2 \cdot 7$ & 0.2 \\
\hline Vegetable oils & $2 \cdot 3$ & 1.6 & 1.9 & 1.9 & 0.2 \\
\hline Animal fat (lard) & 0.1 & 0.1 & 0.2 & $0 \cdot 1$ & 0.2 \\
\hline Other starches & 1.4 & 0.8 & 0.9 & 1.0 & 0.3 \\
\hline Other G2 (molasses) & $2 \cdot 1$ & 1.7 & $2 \cdot 7$ & $2 \cdot 2$ & 2.5 \\
\hline Processed foods (G3) & 5.8 & $7 \cdot 8$ & 4.6 & $6 \cdot 0$ & 0.7 \\
\hline Breads & 3.9 & 4.7 & $2 \cdot 3$ & 3.6 & 1.0 \\
\hline Cheeses & 1.9 & $3 \cdot 1$ & $2 \cdot 3$ & 2.4 & $2 \cdot 3$ \\
\hline $\begin{array}{l}\text { Ultra-processed food and } \\
\text { drink products (G4) }\end{array}$ & $21 \cdot 6$ & $21 \cdot 2$ & $20 \cdot 3$ & $21 \cdot 0$ & 1.0 \\
\hline Cookies, crackers, biscuits & 8.0 & 9.4 & $7 \cdot 4$ & $8 \cdot 2$ & 0.7 \\
\hline $\begin{array}{l}\text { Ice cream/chocolate/instant } \\
\text { desserts }\end{array}$ & 3.5 & 2.9 & 2.9 & $3 \cdot 1$ & 0.8 \\
\hline $\begin{array}{l}\text { Ready-to-heat meals and } \\
\text { mixes }\end{array}$ & 0.0 & 0.0 & 1.0 & 0.3 & $0 \cdot 2$ \\
\hline Sausage & 0.9 & 1.7 & 1.8 & 1.5 & 1.0 \\
\hline Instant sauces & 1.6 & $1 \cdot 1$ & $1 \cdot 1$ & 1.2 & 3.4 \\
\hline Margarines & 0.8 & 0.5 & 0.8 & 0.7 & 0.3 \\
\hline Breakfast cereals & $1 \cdot 1$ & $1 \cdot 1$ & 1.0 & 1.0 & 1.7 \\
\hline $\begin{array}{l}\text { Other sweetened 'fruit' } \\
\text { drinks }\end{array}$ & 4.9 & $4 \cdot 1$ & 4.0 & $4 \cdot 3$ & $2 \cdot 9$ \\
\hline Other G4 (other candies) & 0.9 & 0.5 & 0.4 & 0.6 & $3 \cdot 2$ \\
\hline
\end{tabular}

${ }^{*}$ Average price for the period (\$US/4184 kJ (1000 kcal)).

chicory, cabbage, sweet potato, cassava, beets, carrots, corn cob and kernel); eggs; corn flour; molasses obtained from cane; honey; freshly made breads (with whole and refined flours); cheese; cookies and crackers. City $\mathrm{C}$ did not acquire foods from family farms during the research period. The proportion of total energy attributed to animal fats corresponding to items acquired from family farms by city B $(0.4 \%)$ referred primarily to the acquisition of lard. Meat, beans, leafy vegetables, roots and tuber vegetables were purchased from farmers at similar levels for cities $\mathrm{A}$ and $\mathrm{B}$, although it is worth mentioning that leafy vegetables represented only a small portion of total energy with an average of $1.2 \%$.

Foods purchased only from conventional suppliers were instant desserts, sausages, meats and chicken 


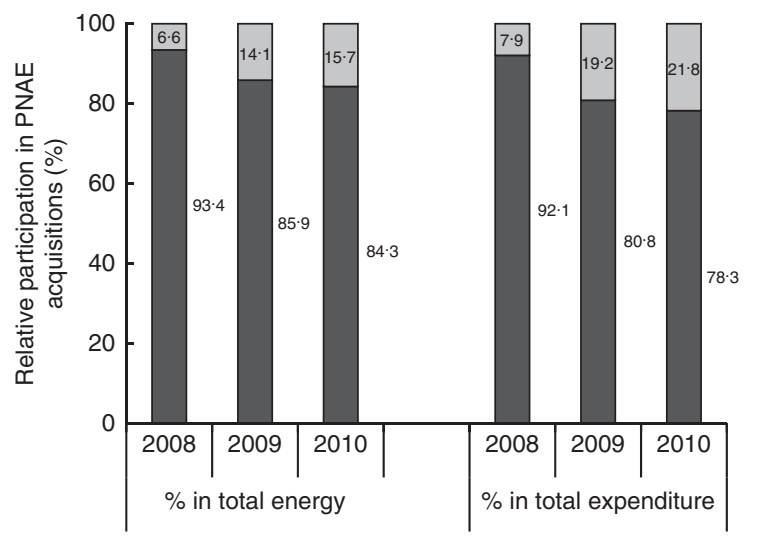

Fig. 1 Relative participation (\%) of different suppliers ( $\square$, conventional suppliers; $\square$, family farms) in PNAE acquisitions in terms of annual energy and expenditure (cost) totals, National School Feeding Program (Programa Nacional de Alimentação Escolar (PNAE)), 2008-2010, Santa Catarina, Brazil

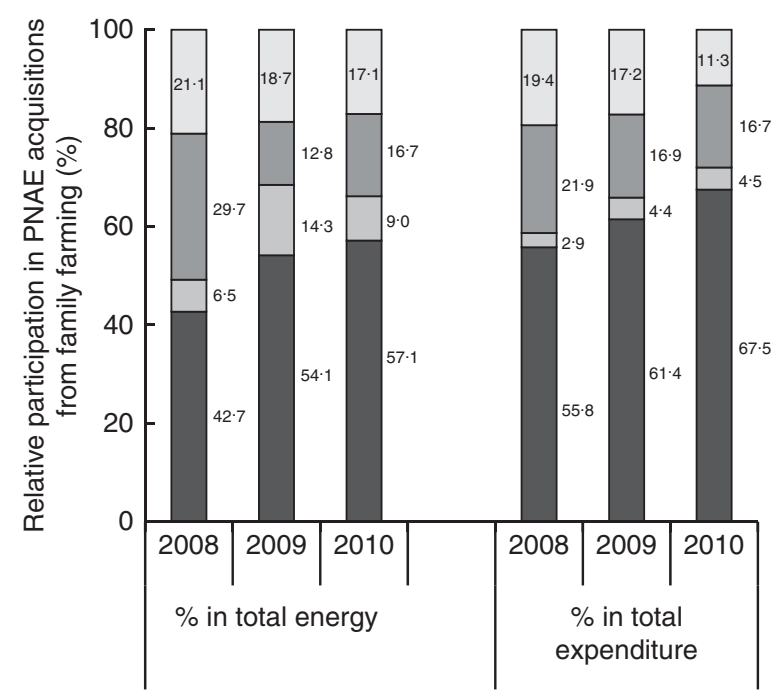

Fig. 2 Relative participation (\%) of different food groups $(\square$, unprocessed and minimally processed foods; $\square$, processed culinary ingredients; $\square$, processed foods; $\square$, ultraprocessed food and drink products) in the annual energy and expenditure (cost) totals of PNAE food acquisitions from family farming, National School Feeding Program (Programa Nacional de Alimentação Escolar (PNAE)), 2008-2010, Santa Catarina, Brazil

extracts and instant sauces, margarines, breakfast cereals, sweetened 'fruit' yoghurts and candies (confectionery). However, foods from all four groups defined by the NOVA classification were purchased from both types of suppliers. In city $\mathrm{C}$, all the different types of foods were acquired from conventional suppliers.

In evaluating the average price, food group, year of acquisition and city, we found that the prices of foodstuffs from family farms were consistently higher than those of conventional suppliers (Table 3). Moreover, the price difference between those suppliers (family farms $v$. conventional) increased over the research period.
Table 3 Average price (\$US/4184 kJ (1000 kcal)) of PNAE acquisitions from conventional suppliers and family farms per city, year and food group, National School Feeding Program (Programa Nacional de Alimentação Escolar (PNAE)), 2008-2010, Santa Catarina, Brazil

\begin{tabular}{lcc}
\hline & \multicolumn{2}{c}{ Average price } \\
\cline { 2 - 3 } Variable & $\begin{array}{c}\text { Family farm } \\
\text { suppliers }\end{array}$ & $\begin{array}{c}\text { Conventional } \\
\text { suppliers }\end{array}$ \\
\hline City A & 1.4 & 0.9 \\
City B & 1.2 & 0.9 \\
City C & - & 1.0 \\
2008 & 1.2 & 1.0 \\
2009 & 1.3 & 0.9 \\
2010 & 1.3 & 0.9 \\
Unprocessed or minimally & 1.6 & 1.5 \\
$\quad$ processed (G1) & & \\
Processed culinary ingredients & 0.6 & 0.3 \\
$\quad$ (G2) & 1.0 & 0.7 \\
Processed foods (G3) & 1.1 & 0.9 \\
Ultra-processed food and drink & & \\
$\quad$ products (G4) & &
\end{tabular}

$(-)$, data not available (city $\mathrm{C}$ did not purchase from family farms during the research period).

Analysis of average prices of food items acquired from family farming $v$. conventional suppliers showed that the former had higher prices for city A. This is likely because this municipality can attract more suppliers in this category (an average of $20.0 \%$ of the total energy for the period) than city B (an average of $13.0 \%$ of the total energy for the period). City $\mathrm{C}$ showed no acquisitions for this period, probably due to issues with management (e.g. knowledge and understanding of legislation, political willingness). The average price (\$US/4184 kJ $(1000 \mathrm{kcal}))$ of total foods purchased from family farms over the study period for all municipalities was $1 \cdot 3$, while acquisitions from conventional suppliers was $0 \cdot 9$.

\section{Discussion}

Agriculture and health are intrinsically related, now more than ever before ${ }^{(20)}$. The implementation of Law 11.947/ $2009^{(5)}$ in Brazil represents a concerted effort to bring these sectors closer together, with the purpose of developing local small family farms while promoting health and well-being through the PNAE; this should facilitate healthier habits and better livelihoods for individuals in surrounding communities ${ }^{(6)}$. Our research on PNAE food acquisition provides data for assessing the initial years of Law $11.947 / 2009^{(5)}$, which represents a new model of public procurement that favours the promotion of health and local development.

Given that updated and reformed legislation became mandatory only in 2010, the analysis of food acquisition through the PNAE bears particular relevance for the inclusion of family agriculture into school feeding ${ }^{(21,22)}$. This process is full of challenges and possibilities, and 
represents an agro-health initiative that is expected to strengthen regional food sustainability while improving community dietary patterns, primarily by focusing on increased consumption of minimally processed foods by schoolchildren $^{(22)}$.

Initial analysis of the relative share of total energy of the food groups and subgroups indicated that the profile for PNAE food acquisition was less favourable in Group 4 than indicated in data from the National Household Budget Survey (Pesquisa de Orçamento Familiar (POF)) for 2008-2009 ${ }^{(12)}$, which was $15 \cdot 6 \%$. On the other hand, the proportion of unprocessed or minimally processed foods in the purchases reported in the PNAE was higher than that reported by the POF $(38.9 \%)^{(12)}$. These findings are relevant, because they point to the importance of discouraging administrators of the PNAE from reproducing the unhealthy eating patterns in that have been accumulating at the population level. Our results show that food from Groups 1 and 2 together provided almost threequarters of the total energy for the programme, which means that unprocessed or minimally processed foods and processed culinary ingredients comprised the majority portion of the PNAE menus during the study period. This finding is compatible with the guidelines of the current Brazilian Food Guide ${ }^{(18)}$ and highlight relevance for breaking with the unhealthy dietary patterns in the school environment. It is also worth mentioning that one of the PNAE aims is to develop food and nutrition education and promote healthy eating at school, and ideally then reaching families and communities.

There was a trend towards a minor increase in the relative share of total energy from ultra-processed foods, and this was associated with a decrease in the share of total cost. Increased affordability and availability of ultraprocessed foodstuffs are particularly concerning, as this facilitates access to unhealthy foods and encourages specific patterns of consumption within the school environment. In other words, food is available at no cost to the student in this environment, determining the pattern and tendency of consumption.

It has previously been suggested that the social and physical environments influence health behaviour ${ }^{(23)}$, and given that school carries the ethos of privileged learning and emphasizes the incorporation of socially conducive behaviour(s) and processes of habit building ${ }^{(24)}$, eating patterns that extend beyond the school community are crucial aspects upon which school feeding impacts.

The heightened presence of Group 4 products in school feeding trends is also a concern, as this indicates an increase in energy density and an unfavourable nutritional profile $^{(25)}$. It is also a well-established fact that the consumption of ultra-processed foods is among the main causes of the current pandemic of obesity and noncommunicable chronic diseases ${ }^{(26)}$. It is thus important to note that in the cities assessed, the present research identified a trend of stability in the relative share of total energy comprised by unprocessed or minimally processed foods (Group 1) with low energy density and high nutrient and fibre contents ${ }^{(25)}$. Likewise, a trend of stability for Group 2 (cooking ingredients) and reduction for Group 3 (processed foods) was observed. Nevertheless, for Group 4 (ultra-processed products), there was a trend towards an increase in relative proportion of energetic value (Table 1), with evidence of the opposite impact on cost (Table 2). This reinforces the possible influence of food pricing on food availability for school meals, as shown at the national level by the $\operatorname{POF}^{(27,28)}$.

In the analysis of suppliers, purchases from family farms during the study period showed a more favourable distribution among the different food groups, indicating the positive approach of the PNAE to integrate local farm suppliers. At the same time, our research showed that acquisition of Group 1 foodstuffs can, in fact, burden the comprehensive implementation of healthier school meals (Figs 1 and 2). While this may seem like an immediate disadvantage, there is the increased income for small, local farming business to consider and, to a certain extent, the demands of local development.

It is noteworthy that the municipalities assessed did not reach the acquisition target for family farming products (a minimum of $30 \%$ of the federal funds allocated to the programme). Nevertheless, we consider that in the first year of the research period (2008) there was no such legal goal yet; in the second year (2009) federal Law 11.947 was approved, but it was only in the third year (2010) that its application became mandatory. Therefore, among the positive aspects that can be pinpointed, we note that annual data analysis of family farms over the study period showed a trend towards improved food purchases. This trend, although positive since it signals a favourable effect of the law and potential to reach and exceed the defined goals, causes increased costs for school feeding.

However, regarding public procurement, we stress the need to overcome the contradiction between efficiency, related to the acquisition of foods for lower prices (value for money), and sustainability, which operates with the idea of ensuring the best value ${ }^{(29)}$. Acquisition of family farming foods is an investment in improving social, health and environmental conditions in the mid and long term, even if this results in higher value of spending compared with conventional supplier purchases ${ }^{(30)}$.

With respect to average prices, city A demonstrated the highest value. Across all analyses the price of acquisitions from family farms was consistently higher, no doubt burdening school meals and perhaps inhibiting regional programme implementation in initial stages (Table 3). We also note the relative affordability of products from conventional suppliers over the study period (Table 3); this may be a strategic move to counterbalance reducing sales volume due to the increased direct acquisition from family farms.

We also observed that the price differences between suppliers (family farm $v$. conventional) increased over the 
research period. Further, the average price of ultraprocessed foods was 30 to $40 \%$ lower than that of unprocessed or minimally processed foods. If this trend persists, then it is important to consider that the proportion of unhealthy foods in schools may increase regardless of the type of supplier. In this sense, research analysing the differences in cost and consumption of ultra-processed foods between the UK and Brazil concluded that the relative affordability of ultra-processed foods in the UK is one reason for higher comparative consumption ${ }^{(31)}$

We also found low quantities of fruits and vegetables in acquisitions, whether provided by family farmers or conventional suppliers. Further, the high combined proportion of foods in Groups 3 and 4 in PNAE acquisitions indicates that there is untapped potential in the region for the introduction of healthier, locally sourced food into school menus.

Our findings also agree with nationwide data indicating that in Brazil, during the past three decades particularly, ultra-processed products are progressively replacing the consumption of healthier, less processed foods regardless of population income level and spending power ${ }^{(25)}$.

The southern region of Brazil stands out in terms of family farming and its contribution to national domestic provisioning $^{(32)}$. An initial assessment of Law 11.947/ $2009^{(5)}$ indicated that in the south, $71.0 \%$ of the municipalities are already acquiring food from family farms for school feeding ${ }^{(22)}$. For this reason, it is worth emphasizing that there are limits in the present study due to development in only three cities with a predominantly agricultural profile, located in a Brazilian region that stands out as having a strong family farming sector. In this sense, both the positive and negative aspects pointed out by our research findings cannot be extrapolated to the whole country. Despite this, our results certainly offer some elements that strengthen the link between family farming and school feeding beyond the local level.

In the municipalities evaluated, meat, milk, cheese, vegetable oils and sweets in general, among other foodstuffs, are in the inventory of food items acquired from family farms. This indicates that farmers who have provided for school meals are reasonably established and have adequate infrastructure to ensure the legal standards for product quality. Similarly, in two small municipalities in São Paulo state, south-eastern Brazil, milk and yoghurt are among the items supplied by family farms for local school menus $^{(33)}$. It is thus necessary to consider that in the approach and debate of school feeding standards, the development of smaller local producers should be facilitated to alleviate regional inequalities and effectively promote local development.

The differences observed among the three sample cities (A, B and C) are surprising, as they are geographically aligned and share similar social, demographic and economic indicators. This scenario indicates that, in principle, there is little reason for the disparities in food acquisition from family farms in terms of prices or even in the types of food purchased. Thus, we can conclude with some degree of certainty that other factors have caused the observed differences in the patterns and behaviour of food acquisition in our three sample cities.

We suggest that the political positioning of managers and technicians and their respective understanding of school feeding can affect programme consistency and make room for discrepancy. Indeed, as other authors have pointed out ${ }^{(9,33)}$, there is a degree of complexity of issues that can impinge upon effective implementation and adherence to the law and the PNAE. Examples of this include the interaction of managers with other sectors, provision for public action, intersectoral partnerships and projects qualifying farmers, and prejudice with regard to the quality of the products of these small local suppliers. There is also strong probability that given the higher price of basic, healthier foods supplied by family farms, local administrations have a degree of resistance to include family agriculture in PNAE food provision. This may lead to a preference for acquisition of foods in Groups 3 and 4 from conventional suppliers.

\section{Conclusion}

Our results indicate that implementation of Law 11.947/ 2009 has produced a positive effect on the regional profile of PNAE food purchase patterns. However, the law is being underutilized and has not produced significant changes in hegemonic dietary patterns. There is still a considerable potential and need to promote healthier habits by strengthening the relationships between family farming and school feeding. Higher food prices of family farms may be one of the restricting factors, and this justifies the creation of a new pricing policy for this specific sector. Moreover, public management must overcome the principle of 'purchases at the lower value', replacing it with the principle of 'purchases at the best value'.

We conclude that the dynamic link between family farming and school feeding, with its timely and intersectoral nature, requires attention and concerted collective efforts to build a more comprehensive working knowledge of this strategy. This will result in positive outcomes for health promotion and local development, and may aid in better defining agro-health initiatives for a sustainable future.

\section{Acknowledgements}

Acknowledgements: The author wishes to acknowledge Dr Carlos Augusto Monteiro and Dr Rafael Moreira Claro, University of São Paulo (USP), for their assistance in providing detailed information on methods used, which are based in the ones that are usually applied in the Brazilian Household Budget Surveys. Financial support: This study 
was developed during postdoctoral internship, supported by the National Council for Scientific and Technological Development (CNPq), Brazil (research fellowship/grant number 102231/2011-7). CNPq had no role in the design, analysis or writing of this article. Conflict of interest: None. Authorship: C.R.P.A.T. is the only author of the study, from its conception to the drafting of the paper submitted for publication. Ethics of buman subject participation: The study was conducted according to the guideline laid down in the Declaration of Helsinki. The Institutional Ethics Board of Universidade Comunitária da Região de Chapecó (Unochapecó) granted ethical approval for collection of survey data.

\section{References}

1. Santos LMP, Santos SMC, Santana LAA et al. (2007) Avaliação de políticas de segurança alimentar e combate à fome no período 1995-2002. 4 - Programa Nacional de Alimentação Escolar. Cad Saude Publica 23, 2681-2693.

2. Chaves LG, Brito RR, Teixeira RM et al. (2007) Programa Nacional de Alimentação Escolar: compromisso com a saúde pública. Nutr Profissional 3, 22-27.

3. Fundo Nacional de Desenvolvimento da Educação (2013) Alimentação Escolar - Dados estatísticos. http://www.fnde. gov.br/index.php/ae-dados-estatisticos (accessed November 2013).

4. Turpin ME (2009) A alimentação escolar como fator de desenvolvimento local por meio do apoio aos agricultores familiares. Segur Aliment Nutr 16, 20-42.

5. Brasil (2009) Lei $n^{o} 11.947$, de 16 de junbo de 2009. Dispõe sobre o atendimento da alimentação escolar e do Programa Dinheiro Direto na Escola. Brasília: Diário Oficial da União.

6. Teo CRPA \& Monteiro CA (2012) Marco legal do Programa Nacional de Alimentação Escolar: uma releitura para alinhar propósitos e práticas na aquisição de alimentos. Rev Nutr 25, 657-668

7. Triches RM \& Schneider S (2010) Reconstruindo o 'elo perdido': a reconexão da produção e do consumo de alimentos através do Programa de Alimentação Escolar no município de Dois Irmãos (RS). Segur Aliment Nutr 17, 1-15.

8. Oliveira RC (2004) A transição nutricional no contexto da transição demográfica e epidemiológica. Rev Min Saude Publica 3, 16-23.

9. Triches RM \& Schneider S (2010) Alimentação escolar e agricultura familiar: reconectando o consumo à produção. Saude Soc 19, 933-945.

10. Instituto Brasileiro de Geografia e Estatística (2010) Cidades@. http://www.ibge.gov.br/cidadesat/topwindow. htm?1 (accessed January 2013).

11. Estado de Santa Catarina (2010) Dados estatísticos. http:// www.spg.sc.gov.br/ (accessed January 2013).

12. Instituto Brasileiro de Geografia e Estatística (2010) Pesquisa de Orçamentos Familiares 2008-2009: Avaliação Nutricional da Disponibilidade Domiciliar de Alimentos no Brasil. Rio de Janeiro: IBGE.

13. Dreon R (2011) Os efeitos do PRONAF sobre o PIB do município de Xaxim - SC no período de 2001 a 2010. Graduate Thesis, Universidade Comunitária da Região de Chapecó

14. Faxinal dos Guedes (2012) Dados Econômicos. http:// www.faxinal.sc.gov.br/ (accessed January 2013).
15. Instituto Brasileiro de Geografia e Estatística (1978) Estudo Nacional das Despesas Familiares - ENDEF: 1974-1975. Rio de Janeiro: IBGE.

16. Núcleo de Estudos e Pesquisas em Alimentação (2011) Tabela Brasileira de Composição de Alimentos - TACO. Campinas: NEPA.

17. US Department of Agriculture, Agricultural Research Service (2005) USDA National Nutrient Database for Standard Reference. http://www.ars.usda.gov/ba/blmrc/ndl (accessed November 2010).

18. Monteiro CA, Cannon G, Levy R et al. (2016) NOVA. The star shines bright. World Nutr 7, 28-38.

19. Claro RM, Maia EG, Costa BVL et al. (2016) Food prices in Brazil: prefer cooking to ultra-processed foods. Cad Saude Publica 32, e00104715.

20. Hawkes C \& Ruel M (2006) The links between agriculture and health: an intersectoral opportunity to improve the health and livelihoods of the poor. Bull World Health Organ 84, 984-990.

21. Villar BS, Schwartzman F, Januario BL et al. (2013) Situação dos municípios do estado de São Paulo com relação à compra direta de produtos da agricultura familiar para o Programa Nacional de Alimentação Escolar (PNAE). Rev Bras Epidemiol 16, 223-226.

22. Saraiva EB, Silva APF, Sousa AA et al. (2013) Panorama da compra de alimentos da agricultura familiar para o Programa Nacional de Alimentação Escolar. Cienc Saude Colet 18, 927-936.

23. Leite FHM, Oliveira MA, Cremm EC et al. (2012) Availability of processed foods in the perimeter of public schools in urban areas. J Pediatr (Rio J) 88, 328-334.

24. Schmitz BA, Recine E, Cardoso GT et al. (2008) Promotion of healthy eating habits by schools: a methodological proposal for training courses for educators and school cafeteria owners. Cad Saude Publica 24, Suppl. 2, S312-S322.

25. Monteiro CA, Levy RB, Claro RM et al. (2011) Increasing consumption of ultra-processed foods and likely impact on human health: evidence from Brazil. Public Health Nutr 14, 5-13.

26. World Health Organization (2003) Diet, Nutrition and the Prevention of Chronic Diseases. Report of a Joint WHO/FAO Expert Consultation. WHO Technical Report Series no. 916. Geneva: WHO.

27. Claro RM \& Monteiro CA (2010) Renda familiar, preço de alimentos e aquisição domiciliar de frutas e hortaliças no Brasil. Rev Saude Publica 44, 1014-1020.

28. Ricardo CZ \& Claro RM (2012) Custo da alimentação e densidade energética da dieta no Brasil, 2008-2009. Cad Saude Publica 28, 2349-2361.

29. Morgan K \& Sonnino R (2008) The School Food Revolution: Public Food and the Challenge of Sustainable Development. London: Earthscan.

30. Sonnino R, Bassinello TL \& Lozano C (2016) School feeding programmes: addressing the challenges of sustainable development. In Alimentação Escolar: Construindo Interfaces entre Saúde, Educação e Desenvolvimento, pp. 35-63 [CRPA Teo and RM Triches, editors]. Chapeco: Argos.

31. Moubarac JC, Claro RM, Baraldi LG et al. (2013) International differences in cost and consumption of ready-toconsume food and drink products: United Kingdom and Brazil, 2008-2009. Glob Public Health 8, 845-856.

32. Guilhoto JM, Ichihara SM, Silveira FG et al. (2007) A importância da agricultura familiar no Brasil e em seus estados. Núcleo de Estudos Agrários e Desenvolvimento Rural (NEAD). http://www.anpec.org.br/encontro2007/ artigos/A07A089.pdf (accessed February 2013).

33. Belik W \& Domene SMA (2012) Experiências de programas combinados de alimentação escolar e desenvolvimento local em São Paulo-Brasil. Agroalimentaria 18, 57-72. 